\title{
Soil Microbial Community Composition and Diversity Remained Unchanged in a Semiarid Grassland in Northwestern China After 7 Years of Nitrogen Addition
}

\section{Qian Guo}

Northwest A\&F University https://orcid.org/0000-0001-7780-8452

\section{Zhongming Wen}

Northwest A\&F University

Hossein Ghanizadeh

Massey University

\section{Cheng Zheng}

Northwest A\&F University

\section{Yongming Fan}

Planning and Design Institute of National Forestry and Grassland Administration

\section{Jinxin Lu}

Northwest A\&F University

\section{Xue Yang}

Northwest A\&F University

Xinhui Yan

Northwest A\&F University

\section{Sihui Chen}

Northwest A\&F University

Wei Li ( $\square$ liwei2013@nwsuaf.edu.cn )

Northwest A\&F University

\section{Research Article}

Keywords: Community weighted-mean traits, Nitrogen addition, 16S rRNA, Microbial community assembly process

Posted Date: December 1st, 2021

DOI: https://doi.org/10.21203/rs.3.rs-1105169/v1

License: () (1) This work is licensed under a Creative Commons Attribution 4.0 International License. Read Full License 


\section{Abstract}

\section{Aims}

Nitrogen $(\mathrm{N})$ deposition is a global environmental problem that can alter community compositions and functions, and consequently, the ecosystem services. In this study, we assessed the responses of aboveground vegetation, surface soil properties and microbial communities to $\mathrm{N}$ addition, and explored the drivers of microbial community in a semiarid steppe ecosystem in northwest of China.

\section{Methods}

Thirty-six $6 \times 10-\mathrm{m}^{2}$ plots composed of six $\mathrm{N}$ addition levels and six replicates were distributed in six columns and six rows. Nine vegetation characteristics and seven soil properties were measured and calculated. Soil microbial characteristics were analyzed by $16 \mathrm{~S}$ rRNA high-throughput sequencing.

\section{Results}

$\mathrm{N}$ addition positively affected aboveground vegetation traits such as the community weighted-mean of leaf nitrogen content $\left(\mathrm{LN}_{\mathrm{CWM}}\right)$. High $\mathrm{N}$ inputs significantly altered the microbial community assembly process from random to deterministic. The microbial community diversity and composition, however, were not sensitive to $\mathrm{N}$ addition. A piecewise structural equation model (SEM) further showed that the microbial community composition was affected by both aboveground vegetation and soil properties. The composition of bacterial communities was mainly regulated by the composition of plant communities and soil total $\mathrm{N}$. In contrast, the composition of fungal communities was driven by soil $\mathrm{pH}$ and the community weighted-mean of specific leaf area $\left(\mathrm{SLA} \mathrm{A}_{\mathrm{CWM}}\right)$. Microbial diversity and composition remained unchanged because their drivers were not affected by $\mathrm{N}$ addition. The results of this research improved our understanding of the response of grassland ecosystems to $\mathrm{N}$ deposition, and provided a theoretical basis for grassland utilization and management under $\mathrm{N}$ deposition.

\section{Introduction}

Anthropogenic activities such as fertilization and fossil fuel burning have increased emissions of reactive nitrogen ( $\mathrm{N}$ ), and atmospheric $\mathrm{N}$ deposition by three to five times over the 20th century (Zhang et al. 2018b). China is one of the hotspots of $\mathrm{N}$ deposition, with $\mathrm{N}$ deposition fluxes of $1.32 \mathrm{~g} \mathrm{~N} \mathrm{~m}^{-2} \mathrm{yr}^{-1}, 2.11 \mathrm{~g} \mathrm{~N} \mathrm{~m}^{-2} \mathrm{yr}^{-1}, 3.78 \mathrm{~g} \mathrm{~N} \mathrm{~m}^{-2} \mathrm{yr}^{-1}$ and $4.00 \mathrm{~g} \mathrm{~N} \mathrm{~m}^{-2} \mathrm{yr}^{-1}$ recorded in the 1980s, 2000s, 20062014 and 2011-2018, respectively (Liu et al. 2013; Xu et al. 2015; Wen et al. 2020). Nitrogen deposition can affect fundamental community processes and ecosystem services (Jones et al. 2014; Zhu et al. 2020). Nitrogen deposition can also improve plant productivity (Avolio et al. 2014) and carbon (C) sequestration in some ecosystems (Lu et al. 2021). However, excess $\mathrm{N}$ inputs can negatively affect ecosystems by increasing soil acidification (Sun et al. 2020), reducing plant diversity (Yang et al. 2011), and diminishing soil microbial biomass and diversity (Liu et al. 2011; Wang et al. 2018a). In addition, excess N inputs have detrimental impacts on microbial community stability and activity (Lv et al. 2017), microbial community structures (Liu et al. 2017) and the utilization efficiency of microbial $\mathrm{C}$ and $\mathrm{N}$ ( Li et al. 2021). A meta-analytic assessment of 151 studies showed that excess $\mathrm{N}$ reduced total microbial biomass, fungal biomass, bacterial biomass, microbial respiration, and microbial community compositions in many terrestrial ecosystems (Zhang et al. 2018b). Also, it has been shown that excess $\mathrm{N}$ increased the relative abundance of copiotrophic phyla (Ascomycota, and Proteobacteria), but reduced that of oligotrophic phyla (Basidiomycota, Acidobacteria and Firmicutes) (Cui et al. 2021; Fierer et al. 2012; Widdig et al. 2020).

Microorganisms play a crucial role in ecosystems by contributing to climate regulation (Birrer et al. 2019), element cycling (Nelson et al. 2016; Trivedi et al. 2016; Yevdokimov et al. 2016), basic soil processes (Chen et al. 2020), crop yields (Liang et al. 2020), and ecosystem sustainability (Toju et al. 2018). However, the global soil microbial community is threatened by $\mathrm{N}$ deposition, with $\mathrm{N}$ deposition negatively affecting soil microbial community structures and the function of ecosystems. Alterations in microbial community are associated with the differences in the community assembly process. Niche theory and neutral theory are two major theoretical models to explain community composition mechanisms in community ecology (Chen et al. 2019). The niche theory posits that the shape of microbial communities is influenced by deterministic abiotic and biotic factors such as environmental conditions and species interactions, whereas the neutral theory asserts that the microbial community assembly is a random diffusion process, and niche differences have no effects on it (Perronne et al. 2017). Several factors can affect microbial community assembly mechanisms, such as land use (Osburn et al. 
2021), salinity (Mo et al. 2021), type of rhizosphere minerals, and soil depth (Luan et al. 2020). How N deposition influences microbial community assembly is a question of importance in designing appropriate management practices to minimize $\mathrm{N}$ deposition in the semiarid grasslands of northwest China.

The drivers changing soil microbial community are complex and difficult to disentangle as changes in soil microbial community can arise through alterations in soil properties (e.g. soil pH, soil dissolved organic carbon, available nitrogen) (Cui et al. 2021; Widdig et al. 2020), plant communities (e.g. biomass, structure) (Leff et al. 2015), interactions between microorganisms or between microorganisms and plants (Bahram et al. 2018; Romdhane et al. 2021), and other factors (e.g. phage) (Chevallereau et al. 2021). Nitrogen addition usually leads to a reduction in soil pH (Sun et al. 2020; Wang et al. 2018c; Widdig et al. 2020). Nitrate leaching caused by excess $\mathrm{N}$ inputs is usually accompanied by some soil cations (e.g. $\mathrm{K}^{+}, \mathrm{Ca}^{2+}$ and $\mathrm{Mg}^{2+}$ ), leading to increased soil acidification (Liu et al. 2011). Soil acidification inhibits the growth and reproduction of fungi, especially arbuscular mycorrhizal fungi (AMF) (Leff et al. 2015; Zhang et al. 2018b).

Temperate grasslands are generally considered to be limited by N ( Avolio et al. 2014; Liu et al. 2011; Vitousek et al. 2010), and N addition can alleviate $\mathrm{N}$ limitation in plants and microorganisms, resulting in changes in community compositions. Changes in plant community compositions, plant community diversity, and plant biomass (aboveground and belowground) as a result of $\mathrm{N}$ deposition strongly influence the microbial community compositions (Lv et al. 2017; Qin et al. 2020; Widdig et al. 2020; Xiao et al. 2020). Therefore, understanding how long-term $\mathrm{N}$ deposition affects soil properties and microbial community is crucial for elucidating the appropriate management for $\mathrm{N}$ deposition in the semiarid grasslands of northwest China.

Changes in plant community and soil properties as a result of $\mathrm{N}$ addition can directly or indirectly affect the species diversity, community assembly process, community composition, microbial biomass and functional activities of soil microbial community (Craig et al. 2021). Here, we sought to determine whether $\mathrm{N}$ deposition altered the diversity, composition, and assembly processes of the bacterial and fungal communities in the semiarid steppe in China. For this, a high-throughput sequencing technology was used to assess the dynamic changes of soil microbial communities on the Loess Plateau in China in response to $\mathrm{N}$ addition. In addition, we studied the drivers affecting microbial community compositions to understand the links between $\mathrm{N}$ addition and microbial communities.

\section{Material And Methods}

\section{Study sites}

This research was carried out at the national permanent scientific research station in the NingXia Yunwu Mountain grassland ecosystem $\left(106^{\circ} 21^{\prime}-106^{\circ} 27^{\prime} \mathrm{E}, 36^{\circ} 10^{\prime}-36^{\circ} 17^{\prime} \mathrm{N}\right)$, Ningxia Hui autonomous region, China. The region is dominated by a middle temperate semiarid climate, with an annual average temperature of $7.0^{\circ} \mathrm{C}$ and an annual average precipitation of $425 \mathrm{~mm}$. The altitude of the area is $1800-$ $2100 \mathrm{~m}$, with the highest peak of $2148.4 \mathrm{~m}$. According to the general soil classification system of China, the soil type is montane greycinnamon soil, which is equivalent to Haplic Calcisol in the FAO/UNESCO system. There are more than 297 plant species in the area, but the main species are Stipa grandis P.A.Smirn, Thymus mongolicus (Ronniger) Ronniger and Artemisia sacrorum Ledeb. (Cheng et al. 2016).

\section{Experimental design and sampling}

Thirty-six $6 \times 10-\mathrm{m}^{2}$ plots composed of six $\mathrm{N}$ addition levels and six replicates were distributed in six columns and six rows. The plots were laid out in a randomized block design. Each plot was separated from the others by a 2-m buffer strip. The fertilization treatments consisted of different amounts of $\mathrm{CO}(\mathrm{NH} 2)_{2}$, namely $0,5,10,20,40$ and $80 \mathrm{~g} \mathrm{~m}^{-2} \mathrm{yr}^{-1}$ (hereafter referred to as N0, N1, N2, N3, N4 and N5), corresponding to $0,2.34,4.67,9.34,18.68$ and $37.35 \mathrm{~g} \mathrm{~N} \mathrm{~m}^{2} \mathrm{yr}^{-1}$, respectively. Each treatment had six replicate plots. The fertilizer was applied annually at the beginning of the growing season (usually in the end of April) from 2013 to 2019 . The fertilizer was applied during a moderate rain event to avoid artificial watering. The level of $\mathrm{N}$ was determined according to the local $\mathrm{N}$ deposition rate index and based on the international and domestic fertilization on the same type of grasslands. Each plot was divided into two subplots. One subplot of 4 $\mathrm{m} \times 6 \mathrm{~m}$ was used for vegetation monitoring, and the other subplot $(6 \mathrm{~m} \times 6 \mathrm{~m})$ was allocated for individual plant sampling. Vegetation monitoring and sampling were conducted using a $1 \mathrm{~m} \times 1 \mathrm{~m}$ quadrat randomly placed in each plot in August 2019. In each subplot, the quadrat was placed at least $0.5 \mathrm{~m}$ away from the edge to avoid edge effects. The coverage, mean height, and abundance of each species were measured and recorded in each quadrat. Above ground material for all species was removed at ground level and placed in envelopes categorized by species. All samples were dried to a constant weight at $80^{\circ} \mathrm{C}$ and weighed. 
In each quadrat, three soil samples were collected at soil depths of 0-10 cm using a $5 \mathrm{~cm}$ diameter cylinder auger. The samples of the same depth were pooled to form a single sample. Three quadrats were selected as replicates. Visible debris was removed from the pooled soil samples and each sample was divided into two subsamples. One soil subsample was immediately placed on ice and transferred to the laboratory where it was stored in a $-80^{\circ} \mathrm{C}$ freezer prior to DNA analysis. The other subsample was air-dried and used for chemical analysis.

\section{Leaf functional trait samples and measurements}

Adjustments in plant functional traits signify the survival strategies of plants to changing environments. In this research, the response of four plant leaf functional traits, namely leaf carbon content (LC), leaf nitrogen content (LN), leaf phosphorus content (LP) and specific leaf area (SLA) to $\mathrm{N}$ addition was evaluated. Leaf samples from 5 to 30 healthy dominant species individuals were collected in each plot. Leaf samples were collected from the upper canopy of each individual plant. The leaf samples collected from the same species were pooled to form a single leaf sample. The pooled samples $(\sim 20 \mathrm{~g})$ were placed in paper bags and dried at $65^{\circ} \mathrm{C}$ for $48 \mathrm{~h}$. The dried leaf samples were used to determine the contents of leaf carbon (LC), nitrogen (LN) and phosphorus (LP).

\section{Determination index and method}

The content of soil organic carbon (OC), and LC were determined using the dichromate oxidation method (Liu et al. 2020). The content of soil total nitrogen (TN) and LN were determined using the Kjeldahl method (Liu et al. 2020). The content of soil total phosphorus (TP) and LP were determined using the ammonium molybdate colorimetric method (Liu et al. 2020). The content of soil alkali-hydrolyzable nitrogen (AN) and soil available phosphorus (AP) were determined using the ISNT (Roberts et al. 2011) and the Olsen methods (Zhang et al. 2016), respectively. The soil pH was measured by an automatic titrator (Metrohm 702, Swiss). Soil moisture content (SMC) was measured the gravimetric method (Liang and Wang, 2020). To assess SLA, images of the sampled leaves were obtained using a scanner (Yaxin-1242), and the images were analyzed using Image $J$ software to estimate the leaf area (Guo et al. 2021). The leaf samples were then oven dried at $65^{\circ} \mathrm{C}$ for $48 \mathrm{~h}$, and weighed. The SLA was estimated using Eq. 1.

\section{SLA = leaf area/dry leaf weight}

Eq.1

The community weighted-mean trait values (CWM) was calculated using Eq. 2.

\section{$\mathrm{CWM}=\sum_{i=1}^{S} p_{i} \times$ trait $_{i}$}

where $p_{i}$ represents the relative contribution of species $i$ to the community, trait $t_{i}$ donates the trait value of species $i$. Plant community richness was expressed by the number of species.

DNA extractions and high-throughput sequencing

The soil samples stored at $-80^{\circ} \mathrm{C}$ were used for total genomic DNA extraction using the CTAB (cetyl trimethyl ammonium bromide) method (Robe et al. 2003). DNA concentration and purity was assessed on $1 \%$ agarose gels. The bacterial $16 \mathrm{~S}$ rRNA genes of the V4 region were amplified following the method outlined previously using the primers 515F (5- C TAYGGGRBGCASCAG - 3) and 806R (5 - GGACTACN GGGTATCT $\forall T$ - 3) (Behrendt et al. 2012). The internal transcribed spacer 1 (ITS1) region of fungi was amplified following the method outlined previously using the primers ITS5-1737F (5- GG $\forall G T \forall \forall G T C G T \forall C \forall G G$ - 3) and ITS2-2043R (5 - GCTGCG T C T CATCGATGC - 3) (Abliz et al. 2003). The PCR products of 16S rRNA and ITS1 genes were used to construct sequencing libraries. The sequencing libraries were prepared using the TruSeq® DNA PCR-Free Sample Preparation Kit (Illumina, USA) following the manufacturer's instructions. The quality of the sequencing libraries was assessed using the Qubit@2.0 Fluorometer (Thermo Scientific) and Agilent Bioanalyzer 2100 system. Eventually, the sequencing libraries were sent to Beijing Novogene Bioinformatics Technology Co., Ltd. (Beijing, China) for high-throughput gene sequencing (Illumina NovaSeq PE250).

\section{Data analysis}

Alpha diversity was applied to analyze the complexity of soil microbial diversity through Chao1, Shannon, and ACE indices. All of these indices were calculated using QIIME (v1.9.1, http://qiime.org/scripts/split_libraries_fastq.html) (Caporaso et al. 2010) in R software 4.1.1. The components of species diversity (i.e. species richness $\left(\mathrm{S}_{\text {plant }}\right)$ and Shannon index of plants $\left.\left(\mathrm{H}_{\text {plant }}\right)\right)$ were calculated using the Microsoft Excel (version 2013) program. The components of functional diversity (i.e. $L_{C W M}, L_{C W M}, L_{C W M}, S L A_{C W M}$ and FDis) were 
calculated using the FD software package (Casanoves et al. 2011) in R software 4.1.1. The effects of $\mathrm{N}$ addition on the components of species diversity and functional diversity were subjected to an analysis of variance (ANOVA), and the means were separated using the LSD test at 5\% probability. All statistical analyses were performed using SPSS (Version 24.0).

The Pearson correlation analysis was performed to analyze the correlation between biotic and abiotic factors, and microbial diversity. The correlation heatmap was constructed using the OmicStudio tools at https://www.omicstudio.cn (Friedman and Alm 2012). The assembly processes (random vs. non-random) was assessed using a null model in the EcoSim R package, and the checkerboard score (C-score) was used to test the null hypothesis of the assembly process. The coefficient of niche width was calculated using the spaa package. The species contributing to dissimilarities in microbial community were determined using similarity percentage analysis (SIMPER) in the vegan package. Principal coordinates analysis (PCoA) and permutational multivariate analysis of variance (PERMANOVA) were used to determine the changes in microbial community compositions. The Kruskal-Wallis rank-sum test in the linear discriminant analysis effect size (LEfSe) method was used to identify the microbial taxa significantly affected by different $\mathrm{N}$ addition treatments following the method outlined previously (Segata et al. 2011). The linear discriminant analysis (LDA) (LDA > 4) was performed to estimate the effect size of each $\mathrm{N}$ level. The relationship between selected biotic and abiotic factors, and microbial community compositions was assessed using the piecewise structural equation model (SEM) (Lefcheck 2016). The SEM was performed using the piecewiseSEM package. Various criteria were used to determine the goodness of fit of the SEM model, including Fisher's C statistic and AIC.

The raw sequencing reads from the high-throughput sequencing were spliced and filtered using FLASH (v1.2.7, http://ccb.jhu.edu/software/FLASH/) (Magoč and Salzberg 2011) and QIIME (v1.9.1, http://qiime.org/scripts/split_libraries_fastq.html) (Caporaso et al. 2010), respectively, to obtain the effective tags. Operational taxonomic units (OTUs) clustering and species classification were performed on the effective tags. The sequences were analyzed using Uparse software (Uparse v7.0.1001), and sequences with $\geq 97 \%$ similarity were assigned to the same OTUs, with the largest abundance within OTUs being selected as the representative sequence. The representative sequences were then annotated using the Silva Database (http://www.arb-silva.de/) (Quast et al. 2013) based on the Mothur algorithm.

\section{Result}

\section{The vegetation characteristics and soil properties across $\mathbf{N}$ addition treatments.}

The $\mathrm{N}$ addition had a positive effect on $\mathrm{LN}_{\mathrm{CWM}}$, and foliar N/P (Table 1). For instance, $\mathrm{LN}_{\mathrm{CWM}}$ and foliar N/P increased by $54 \%$ and $93 \%$ at N5 plots, respectively. The increase in foliar N/P of dominant species in grassland communities indicates that dominant plants gradually shifted from $\mathrm{N}$-limited to P-limited. The $\mathrm{N}$ addition had a significantly negative influence on diversity $\left(\mathrm{S}_{\text {plant }}\right.$ and $\left.\mathrm{H}_{\text {plant }}\right)$. In addition, $\mathrm{N}$ addition had a positive effect on biomass, and but negatively affected LP $\mathrm{CWM}_{\text {and SLA }}$ CWM, though the effect was not significant. Increasing the level of $\mathrm{N}$ resulted in an inconsistent response in $\mathrm{LC}_{\mathrm{CWM}}$ and FDis; however, no significant effects were recorded for both parameters across all $\mathrm{N}$ addition treatments. The results of PCoA and PERMANOVA showed that $\mathrm{N}$ addition did not cause significant changes in plant community compositions (Fig. S2a, Table S1). An evaluation of soil properties showed that N addition had a small effect on soil properties (Table 2). The results showed that increasing the level of $\mathrm{N}$ resulted in no significant changes in OC, TN, AN, TP, $\mathrm{AP}, \mathrm{pH}, \mathrm{SMC}$, and these soil properties almost remained unaffected with $\mathrm{N}$ addition. 
Table 1

The vegetation characteristics across $\mathrm{N}$ addition treatments. Values are means \pm standard error $(n=6)$. Different letters within each row indicate significant differences $(P<0.05)$. $S_{\text {plant }}$ represents the species richness of plants, $\mathrm{H}_{\text {plant }}$ represents $S$ hannon index of plants.

\begin{tabular}{|c|c|c|c|c|c|c|c|c|}
\hline Parameters & NO & N1 & N2 & N3 & N4 & N5 & $F$ & $P$ \\
\hline $\mathrm{LC}_{\mathrm{CWM}}\left(\mathrm{g} \mathrm{kg}^{-1}\right)$ & $490.3 \pm 3.3$ & $480.3 \pm 5.1$ & $474.5 \pm 3.8$ & $470.0 \pm 3.9$ & $486.7 \pm 5.5$ & $483.0 \pm 7.2$ & 2.318 & 0.068 \\
\hline $\mathrm{LN}_{\mathrm{CWM}}\left(\mathrm{g} \mathrm{kg}^{-1}\right)$ & $15.0 \pm 0.3 e$ & $17.9 \pm 0.8 \mathrm{~cd}$ & $18.3 \pm 0.5 c$ & $20.3 \pm 0.4 b c$ & $21.8 \pm 0.6 a b$ & $23.1 \pm 1.1 \mathrm{a}$ & 19.240 & 0.000 \\
\hline $\operatorname{LP}_{\mathrm{CWM}}\left(\mathrm{g} \mathrm{kg}^{-1}\right)$ & $1.32 \pm 0.04$ & $1.22 \pm 0.11$ & $1.16 \pm 0.03$ & $1.09 \pm 0.05$ & $1.08 \pm 0.06$ & $1.08 \pm 0.10$ & 2.013 & 0.105 \\
\hline $\operatorname{SLA}_{C W M}\left(\mathrm{~cm}^{-2} \mathrm{~g}^{-1}\right)$ & $143.2 \pm 11.0$ & $126.8 \pm 8.5$ & $131.2 \pm 5.2$ & $116.2 \pm 6.0$ & $109.6 \pm 2.8$ & $127.0 \pm 10.0$ & 2.263 & 0.074 \\
\hline Foliar N/P ratio & $11.3 \pm 0.5 d$ & $15.0 \pm 1.8 \mathrm{c}$ & $15.8 \pm 1.7 c$ & $18.8 \pm 2.2 b$ & $20.3 \pm 1.6 a b$ & $21.8 \pm 2.6 a$ & 26.845 & 0.000 \\
\hline FDis & $1.4 \pm 0.1$ & $1.3 \pm 0.1$ & $1.3 \pm 0.1$ & $1.6 \pm 0.1$ & $1.3 \pm 0.2$ & $1.2 \pm 0.2$ & 0.869 & 0.513 \\
\hline$S_{\text {plant }}$ & $13.3 \pm 1.0 \mathrm{a}$ & $11.5 \pm 1.1 \mathrm{ab}$ & $13.3 \pm 1.0 \mathrm{a}$ & $9.5 \pm 1.2 b$ & $9.7 \pm 0.9 \mathrm{~b}$ & $8.7 \pm 1.2 b$ & 3.704 & 0.010 \\
\hline $\mathrm{H}_{\text {plant }}$ & $2.3 \pm 0.1 a$ & $2.0 \pm 0.1 \mathrm{ab}$ & $2.2 \pm 0.1 a$ & $1.9 \pm 0.1 b c$ & $1.8 \pm 0.1 b c$ & $1.7 \pm 0.1 c$ & 4.023 & 0.007 \\
\hline Biomass $\left(\mathrm{g} \mathrm{m}^{-2}\right)$ & $202.0 \pm 17.7$ & $280.0 \pm 37.0$ & $304.6 \pm 41.8$ & $296.1 \pm 71.1$ & $484.5 \pm 108.6$ & $330.2 \pm 25.4$ & 2.492 & 0.053 \\
\hline
\end{tabular}

Table 2

Soil properties across $\mathrm{N}$ application treatments. Values are means \pm standard error $(\mathrm{n}=3)$. Different letters within each row indicate significant differences $(P<0.05)$.

\begin{tabular}{|lllllllll|}
\hline Parameters & N0 & N1 & N2 & N3 & N4 & N5 & $\boldsymbol{F}$ & $P$ \\
\hline $\mathrm{OC}\left(\mathrm{g} \mathrm{kg}^{-1}\right)$ & $24.90 \pm 1.55$ & $24.88 \pm 1.91$ & $27.80 \pm 1.43$ & $26.37 \pm 2.58$ & $27.13 \pm 1.14$ & $26.38 \pm 0.49$ & 0.508 & 0.765 \\
\hline $\mathrm{TN}\left(\mathrm{g} \mathrm{kg}^{-1}\right)$ & $2.63 \pm 0.32$ & $2.60 \pm 0.33$ & $2.93 \pm 0.30$ & $2.77 \pm 0.36$ & $2.61 \pm 0.58$ & $2.71 \pm 0.15$ & 0.367 & 0.862 \\
\hline $\mathrm{AN}\left(\mathrm{mg} \mathrm{kg}^{-1}\right)$ & $67.90 \pm 4.28$ & $70.00 \pm 4.50$ & $78.40 \pm 5.30$ & $82.37 \pm 5.75$ & $77.70 \pm 2.52$ & $72.37 \pm 6.96$ & 1.177 & 0.376 \\
\hline $\mathrm{TP}\left(\mathrm{g} \mathrm{kg}^{-1}\right)$ & $0.62 \pm 0.04$ & $0.62 \pm 0.02$ & $0.62 \pm 0.01$ & $0.60 \pm 0.04$ & $0.62 \pm 0.01$ & $0.61 \pm 0.02$ & 0.260 & 0.926 \\
\hline $\mathrm{AP}\left(\mathrm{mg} \mathrm{kg}^{-1}\right)$ & $3.10 \pm 0.07$ & $2.90 \pm 0.40$ & $3.17 \pm 0.20$ & $2.01 \pm 0.09$ & $3.16 \pm 0.35$ & $2.82 \pm 0.32$ & 2.673 & 0.076 \\
\hline $\mathrm{pH}$ & $8.25 \pm 0.05$ & $8.26 \pm 0.04$ & $8.22 \pm 0.04$ & $8.30 \pm 0.03$ & $8.27 \pm 0.04$ & $8.26 \pm 0.05$ & 0.393 & 0.845 \\
\hline $\mathrm{SWC}(\%)$ & $21.55 \pm 0.90$ & $21.53 \pm 0.75$ & $23.95 \pm 0.51$ & $23.34 \pm 1.43$ & $23.41 \pm 1.21$ & $22.52 \pm 1.88$ & 0.677 & 0.649 \\
\hline
\end{tabular}

\section{The microbial communities across $\mathrm{N}$ addition treatments.}

\section{Diversity of microbial communities.}

A total of 1,064,911 bacterial sequences were obtained from all soil samples, with an average of 59,162 sequences per sample, and the sequencing results yielded a total of 10,650 bacterial OTUs. There was also a total of 1,079,258 fungal sequences (59,959 on average) from all samples, which were clustered into 6900 OTUs. According to the results, there were no significant changes in bacterial a-diversity (ACE, Chao 1 and Shannon) across all $\mathrm{N}$ addition treatments (Table 3). Also, there was no significant change in fungal a-diversity across all $\mathrm{N}$ addition treatments. Spearman's correlation coefficients showed that soil microbial a-diversity was weakly correlated with soil properties and vegetation characteristics (Fig. S1). Changes in soil bacterial richness (ACE, and Chao1 index) exhibited a negative correlation with $S L A_{C W M}\left(R^{2}=-0.58, P=0.014 ; R^{2}=-0.60, P=0.011\right)$ only (Fig. S1a). However, soil fungal diversity (ACE, Chao1 and Shannon indices) was weakly correlated with all factors (Fig. S1b). 
Table 3

Soil bacterial (B) and fungal (F) a-diversity of different $\mathrm{N}$ application gradients. Values are means \pm standard error ( $\mathrm{n}=3$ ). Different letters indicate significant differences $(P<0.05)$.

\begin{tabular}{|c|c|c|c|c|c|c|c|c|}
\hline Parameters & NO & N1 & N2 & N3 & N4 & N5 & $F$ & $P$ \\
\hline B_ACE & $4140.0 \pm 61.1$ & $4115.7 \pm 166.2$ & $4270.7 \pm 54.5$ & $4312.7 \pm 26.4$ & $4266.3 \pm 83.5$ & $4125.1 \pm 162.7$ & 0.670 & 0.654 \\
\hline B_Chao1 & $4034.7 \pm 59.3$ & $4000.8 \pm 160.2$ & $4158.5 \pm 46.6$ & $4193.2 \pm 42.9$ & $4184.4 \pm 71.9$ & $4041.1 \pm 159.5$ & 0.692 & 0.639 \\
\hline B-Shannon & $9.70 \pm 0.02$ & $9.53 \pm 0.16$ & $9.71 \pm 0.05$ & $9.72 \pm 0.06$ & $9.69 \pm 0.07$ & $9.66 \pm 0.10$ & 0.650 & 0.667 \\
\hline F_ACE & $2460.9 \pm 207.2$ & $2051.2 \pm 272.7$ & $2109.3 \pm 158.8$ & $2738.5 \pm 445.2$ & $2508.7 \pm 253.7$ & $2263.5 \pm 298.8$ & 0.833 & 0.551 \\
\hline F_Chao1 & $2382.1 \pm 195.0$ & $2005.3 \pm 307.0$ & $2024.5 \pm 142.5$ & $2699.5 \pm 469.5$ & $2453.7 \pm 264.5$ & $2207.0 \pm 267.1$ & 0.843 & 0.545 \\
\hline F-Shannon & $7.30 \pm 0.43$ & $6.74 \pm 0.30$ & $6.52 \pm 0.13$ & $7.81 \pm 0.30$ & $6.93 \pm 0.55$ & $6.84 \pm 0.55$ & 1.304 & 0.325 \\
\hline
\end{tabular}

\section{Composition of microbial communities.}

The dominant phyla of the bacterial community were Proteobacteria (34.3-40.5\%), Acidobacteria (22.5-25.2\%), Actinobacteria (9.6-15.5\%) and Gemmatimonadetes (6.3-7.9\%) (Fig. 1a). There were no significant changes in relative abundance of the bacterial community across all N addition treatments. The dominant phyla of the fungal community were Ascomycetes (21.7-42.8\%), Mortierellomycota (9.6-22.0\%) and Basidiomycetes (5.9-24.2\%) (Fig. 1b). The results showed that $\mathrm{N}$ addition increased the relative abundance of Ascomycetes while it decreased the relative abundance of Basidiomycetes compared with the control.

LEfSe was used to determine the taxa that significantly differed in abundance under varied levels of $\mathrm{N}$ addition. For fungal communities, the significantly abundant taxa were Periconiaceae (at the family level) and Periconia (at the genus level) at N4 plots (Fig. S2b). However, Helotiales (at the order level) and Roesleria (at the genus level) were significantly abundant at N5 plots. The biomarkers of fungal community were associated with the Phylum Ascomycetes. However, no biomarkers were observed in the bacterial community across all $\mathrm{N}$ addition treatments (Fig. S2a).

PCoA was used to analyze changes in microbial community compositions across all N addition treatments, and PERMANOVA analysis was used to determine significant differences in microbial community compositions. PCoA showed that all plots were clustered together without significant separations (Fig. S3). PERMANOVA analysis showed that there was no significant change in bacterial $(P=0.879)$ and fungal $(P=0.060)$ community compositions across all $\mathrm{N}$ addition treatments (Table S1). Therefore, $\mathrm{N}$ addition did not change microbial community compositions.

\section{Assembly and species turnover of microbial communities.}

The niche width of microbial communities almost remained unchanged under different levels of $\mathrm{N}$ addition (Fig. S4). However, $\mathrm{N}$ altered the balance between random and deterministic processes in the microbial community (Fig. 2). C-score results showed that the value of standardized effect size (SES) changed significantly with increasing the level of $\mathrm{N}$. Bacterial $(\mathrm{N} 5, P<0.001)($ Fig. 2a, Table S2) and fungal $(\mathrm{N} 3, P<0.005 ;$ N4, P<0.001; N5, P<0.001) (Fig. 2b, Table S2) communities were transformed from random to deterministic processes in high levels of $\mathrm{N}$.

Richness-based species exchange ratio (SERr) was used to quantify species turnover in microbial communities (Fig. 3a). The SERrs of bacterial and fungal communities ranged from $0.40-0.41$ and $0.56-0.63$, respectively. The SERrs of fungal communities were greater than those of bacterial communities, suggesting that the fungal communities were more susceptible to $\mathrm{N}$ addition. To explore the effects of species turnover on microbial community formation, the contribution of extinct and immigrated OTUs to the changes in microbial richness and community structure was assessed. In the bacterial communities, the immigrated OTUs accounted for more than $23 \%$ of the OTU richness under N addition, with the lowest (23.91\%) and highest (29.59\%) proportions recorded at N1 and N3 plots, respectively (Fig. 3b). In addition, 22.18 to $25.48 \%$ of the native OTUs were categorized as extinct OTUs, with the lowest and highest proportions recorded at N4 and N1 plots, respectively. In the fungal communities, the proportion of immigrated OTUs in the OTU richness under N addition varied from 28.04 to $52.00 \%$, with the lowest and highest proportions recorded at N2 and N3 plots, respectively. The rate of OTUs extinction ranged from 30.17 to $52.93 \%$, with the lowest and highest proportions recorded at N3 and N2 plots, respectively. These results indicated that $\mathrm{N}$ addition altered the OTU richness of microbial community. Also, it was noted that $\mathrm{N}$ addition led to higher proportions of immigrated and extinct OTUs in the fungal communities than the bacterial communities, indicating that fungal community compositions 
were more sensitive to $\mathrm{N}$ addition. However, the immigrated and extinct OTUs accounted for a small proportion of the relative abundance in microbial communities, and the proportions in bacterial and fungal communities varied from 1.25 to $1.85 \%$ and 2.13 to $5.56 \%$, respectively. A high proportion of microbial richness along with a low proportion of community compositions indicate that species turnover had a greater contribution to the microbial richness than the microbial community structure. Similar results were also demonstrated by the SIMPER analysis, which showed that the immigrated and extinct OTUs contributed no more than $8 \%$ to the variation in microbial communities between the $\mathrm{N}$ treatments and control (Fig. 3c).

\section{Drivers of microbial communities.}

The structural equation model (SEM) illustrating the effects of soil properties and vegetation characteristics on soil microbial compositions and diversity is illustrated in Fig. 4. According to the results, 85 and $44 \%$ of the variance in bacterial and fungal community compositions, respectively, was explained by the fitted model (Fig. 4a). The results showed that TN and plant community, respectively, had significantly positive and negative effects on the bacterial community, whereas $\mathrm{pH}$ and $S \mathrm{~A}_{\mathrm{CWM}}$ had significantly negative influences on the fungal community. Overall, the results showed that plant community compositions $(P<0.05)$ and TN $(P<0.001)$ were important driving factors for bacterial community compositions, whereas fungal community compositions were mainly regulated by $\mathrm{pH}(P<0.05)$ and $\operatorname{SLA}_{C W M}(P<0.05)$. A significant negative effect of SLA ${ }_{C W M}$ on bacterial diversity was revealed by the model (Fig. $\left.4 \mathrm{~b}\right)$. However, none of the factors associated with soil properties and vegetation characteristics had a significant effect on fungal diversity, which was consistent with the results illustrated in Figure S1. Nitrogen addition had no significant effects on microbial community diversity and compositions. Nitrogen addition significantly affected $\mathrm{LN}_{\mathrm{CWM}}$ and $\mathrm{H}_{\text {plant }}$, though they had no significant impacts on microbial community diversity and compositions. However, the factors (i.e. plant community compositions, TN and SLA $\mathrm{CWM}_{\mathrm{M}}$ ) that significantly affected the diversity and compositions of microbial community were not significantly influences by $\mathrm{N}$ addition.

\section{Discussion}

\section{Changes in vegetation characteristics and soil properties under $\mathrm{N}$ addition.}

The results of this research showed that $\mathrm{N}$ inputs did not alter plant community compositions, though $\mathrm{N}$ addition affected leaf functional traits, and species diversity, indicating that $\mathrm{N}$ deposition altered plant community functions (Tatarko and Knops 2018; Xu et al. 2021; Zhang et al. 2018a; Zheng et al. 2017). However, increased availability of $\mathrm{N}$ can limit the availability of other elements, such as $\mathrm{P}$ (Sardans et al. 2016). Our results showed that $\mathrm{N}$ addition reduced $\mathrm{LP}_{\mathrm{CWM}}$, but it increased foliar N/P ratio of dominant species, indicating the limitation of $\mathrm{P}$ availability to plants as a result of $\mathrm{N}$ deposition. It has been suggested that excessive $\mathrm{N}$ inputs can increase leaf nitrogen contents leading to an increase in the consumption of phosphorus in leaves to promote plant growth, which results in a decline in leaf phosphorus contents (You et al. 2018). In this research, it was noted that increasing $\mathrm{N}$ inputs resulted in a reduction in SLA $A_{C W M}$. The reduction in leaf phosphorus contents can adversely affect photosynthesis capacity of leaves leading to a decline in SLA (Zheng et al. 2017).

In this research it was noted that $\mathrm{N}$ addition did not lead to a significant change in soil $\mathrm{pH}, \mathrm{TN}$ and $\mathrm{AN}$. The absence of changes in soil $\mathrm{pH}$ by $\mathrm{N}$ addition in this study can be due to the calcareous nature of soil in the area where this study was conducted. Due to their high $\mathrm{pH}$ buffering capacity, calcareous soils are resistant to soil acidification caused by long-term nitrogen applications (Yang et al. 2011). The lack of change in TN and AN can be due to the absence of a significant change in the balance between soil $\mathrm{N}$ inputs and outputs. Upon application, urea is rapidly hydrolyzed to ammonium ions, which are either absorbed by plants and soil colloids, or subjected to rapid volatilization in form of ammonia (Liu et al. 2011). Nitrogen can also be lost through other processes such as nitrification, denitrification, $\mathrm{N}_{2} \mathrm{O}$ emission, and leaching (Liu et al. 2011; Lu et al. 2011). However, in our research, the mechanism underlying the changes in the dynamic of $\mathrm{N}$ and its relation to TN and $\mathrm{AN}$ under different levels of $\mathrm{N}$ addition remained unknow as it was outside the scope of this study, but it needs further investigation.

\section{Changes in microbial community diversity and assembly under $\mathrm{N}$ addition.}

Nitrogen deposition has been known as one of the major factors adversely affecting terrestrial biodiversity in all ecosystems (Yang et al. 2020). Several studies have shown that $\mathrm{N}$ addition reduced microbial diversity (Dai et al. 2018; Wang et al. 2018a; Wu et al. 2019), which is in disagreement with the results obtained in the present research where $\mathrm{N}$ addition did not cause significant changes in microbial diversity. Similarly, results from a global experiment of $\mathrm{N}$ addition at 25 grassland sites showed that $\mathrm{N}$ addition had a small effect on microbial diversity (Leff et al. 2015), indicating that grasslands may have the ability to maintain microbial diversity under $\mathrm{N}$ deposition. The inconsistent response of microbial diversity to $\mathrm{N}$ addition recorded among several studies suggests that the effects of $\mathrm{N}$ addition on 
microbial diversity can be varied across different environments, ecosystem types, soil types and vegetation compositions. Our results showed that almost all key vegetation characteristics and soil properties were weakly correlated with changes in microbial diversity. However, there was a significantly negative correlation between SLA ${ }_{C W M}$ and bacterial diversity. In contrast to our results, previous studies have reported a significant correlation between soil properties (e.g. soil pH) and microbial diversity (Zeng et al. 2016; Zhou et al. 2020), suggesting that the response of microbial diversity to soil properties depends on environmental habitats, soil types, the range of $\mathrm{pH}$, and the size of samples (Li et al. 2016).

Both deterministic and random processes can drive the assembly of microbial communities, but the relative importance of each process can be determined by the environmental heterogeneity (Liu et al. 2019). In the present study, a null model was used to assess the response of microbial community assembly to $\mathrm{N}$ addition. The results showed that the microbial community was initially dominated by the random processes, but the relative importance of deterministic processes increased with increasing the level of $\mathrm{N}$. This result implies that microbial communities were controlled by random processes in the control group, whereas the deterministic processes dominated in high levels of $\mathrm{N}$ (Dini-Andreote et al. 2015). It was also noted that the fungal community was more sensitive to $\mathrm{N}$ addition than the bacterial community as the change in the assembly process of the fungal community occurred in lower levels of N. Similar results have been reported from other studies (Dai et al. 2017; Liu et al. 2017).

\section{Microbial community composition and its driving factors under $\mathbf{N}$ addition.}

The results of the present research showed that the microbial community composition did not change significantly under $\mathrm{N}$ deposition. In addition, it was noted that the relative abundance of the dominant bacterial community phyla, including Proteobacteria, Acidobacteria, Actinobacteria, Gemmatimonadetes, Firmicutes, Chloroflexi, and Rokubacteria, did not change significantly under $\mathrm{N}$ addition, which is inconsistent with the copiotrophic hypothesis (Fierer et al. 2012). According to the copiotrophic hypothesis, increasing $\mathrm{N}$ inputs can lead to a decline in the abundance of oligotrophic taxa while the abundance of copiotrophic taxa increases under N addition (Li et al. 2015). Fungi compared to bacteria are more sensitive to $\mathrm{N}$ addition (Freedman et al. 2015). Although the composition of fungal community did not change, the relative abundance of dominant phyla and some taxa of fungal community changed significantly under $\mathrm{N}$ addition. Compared with the control group, $\mathrm{N}$ addition increased the relative abundance of Ascomycota while the relative abundance of Basidiomycetes decreased with increasing $\mathrm{N}$ inputs. This observation is consistent with the prediction of copiotrophic hypothesis (Li et al. 2015). The species of two genera, Periconia, and Roes/eria whose relative abundance increased significantly with increasing $N$ inputs were considered plant-pathogenic fungi (Neuhauser et al. 2011; Markovskaja and Kačergius 2014), indicating that $\mathrm{N}$ addition can increase the risk of plant diseases. The high rates of OTUs immigration and extinction, and the low relative abundance of OTUs suggest that $\mathrm{N}$ addition may have caused changes in rare taxa rather than common taxa. In addition, no significant changes in the bacterial community compositions were observed under $\mathrm{N}$ addition in the present study, suggesting that the immigration and extinction of OTUs had a low contribution to the variation in the bacterial community compositions.

Our results showed that the composition of bacterial and fungal communities were insensitive to $\mathrm{N}$ addition. According to the SEM, plant community compositions, TN, soil pH and SLA ${ }_{\mathrm{CWM}}$ were important factors affecting compositions of microbial community. Plant community compositions can shape microbial community compositions in soil as different soil microorganisms exhibit different host plant preferences (Wippel et al. 2021). Plant community compositions can also influence microbial community compositions through foliar litter inputs (Bani et al. 2018), with the characteristic of litter playing a crucial role in selecting microbial communities with different catabolic pathways (Sagova-Mareckova et al. 2011). Several studies have shown that N addition mainly affected microbial community compositions by changing soil pH (Wang et al. 2018b; Widdig et al. 2020). However, in this research, $\mathrm{N}$ addition led to no significant changes in the $\mathrm{pH}$ of soil, possibly due to the high capacity of the soil to resist pH change (Huang et al. 2021). This observation is consistent with the results from other studies where no significant changes in soil pH led to no changes in microbial community compositions under $\mathrm{N}$ addition (Leff et al. 2015; She et al. 2018). In addition, excess $\mathrm{N}$ may have limited the availability of other resources (e.g. C and P), and thus it limited the ability of microorganisms to utilize additional N in their favour (Cui et al. 2020; Ramirez et al. 2010). The absence of response of microbial community compositions to $\mathrm{N}$ addition can be due to the lack of changes in soil pH, TN and plant community compositions. The insensitive response of microbial communities to $\mathrm{N}$ addition has been observed in other semiarid grasslands (Carey et al. 2015; McHugh et al. 2017).

\section{Conclusion}

In this research, the response of plants, soil and microbial community to $\mathrm{N}$ deposition was investigated. The results showed that plants compared to soil properties and microorganisms were more sensitive to $\mathrm{N}$ deposition. Nitrogen addition increased $\mathrm{LN}_{\mathrm{CWM}}$ and foliar N/P ratio, and as a result, it led to $\mathrm{P}$ limitation. Limitation of $\mathrm{P}$ has a detrimental impact on ecosystem productivity; thus, in grasslands, $\mathrm{P}$ 
needs to be supplied along with $\mathrm{N}$ application to improve the availability of soil $\mathrm{P}$ to plants, and to maintain the dynamic balance between $\mathrm{P}$ and $\mathrm{N}$. The results of this research also showed that $\mathrm{N}$ addition only affected microbial assembly, while no significant effects on microbial diversity and compositions were observed under $\mathrm{N}$ addition. In addition, it was noted that the composition of microbial community was regulated by both vegetation characteristics and soil properties. Based on the SEM, plant community composition and TN determined the bacterial community compositions, while the composition of fungal community was mainly regulated by SLA $A_{C W M}$ and soil pH. These results imply that at our study sites, both plant community composition and TN were better predictors of bacterial community compositions, whereas both $\mathrm{SLA}_{\mathrm{CWM}}$ and soil $\mathrm{pH}$ were better predictors of fungal community compositions. Studying the relationship between microbial community and $\mathrm{N}$ deposition improves our understandings of the response of grassland ecosystems to $\mathrm{N}$ deposition, as well as grassland management, utilization and conservation under $\mathrm{N}$ deposition in the future.

\section{Declarations}

\section{Declaration of competing interest}

The authors declare that they have no known competing financial interests or personal relationships that could have influenced the work reported in this paper.

\section{Acknowledgments}

This work was financially supported by the National Natural Sciences Foundation of China $(41977077,41601586)$ and Natural Science Foundation of Shaanxi Province of China (2020JM-162). We are grateful to the editor and anonymous reviewers for their constructive comments and suggestions. We also thank Wang (from the University of California, Irvine) for improving the English language.

\section{References}

1. Abliz P, Fukushima K, Takizawa K, Nieda N, Miyaji M, Nishimura K (2003) Rapid identification of the genus Fonsecaea by PCR with specific oligonucleotide primers. J Clin Microbiol 41:873-876. https://doi.org/10.1128/JCM.41.2.873-876.2003

2. Avolio ML, Koerner SE, La Pierre KJ, Wilcox KR, Wilson GWT, Smith MD, Collins SL (2014) Changes in plant community composition, not diversity, during a decade of nitrogen and phosphorus additions drive above-ground productivity in a tallgrass prairie. $J$ Ecol 102:1649-1660. https://doi.org/10.1111/1365-2745.12312

3. Bahram M, Hildebrand F, Forslund SK, Anderson JL, Soudzilovskaia NA, Bodegom PM, Bengtsson-Palme J, Anslan S, Coelho LP, Harend H, Huerta-Cepas J, Medema MH, Maltz MR, Mundra S, Olsson PA, Pent M, Põlme S, Sunagawa S, Ryberg M, Tedersoo L, Bork $P$ (2018) Structure and function of the global topsoil microbiome. Nature 560:233-237. https://doi.org/10.1038/s41586-018-0386-6

4. Bani A, Pioli S, Ventura M, Panzacchi P, Borruso L, Tognetti R, Tonon G, Brusetti L (2018) The role of microbial community in the decomposition of leaf litter and deadwood. Appl Soil Ecol 126:75-84. https://doi.org/10.1016/j.apsoil.2018.02.017

5. Behrendt L, Larkum AWD, Trampe E, Norman A, Sørensen SJ, Kühl M (2012) Microbial diversity of biofilm communities in microniches associated with the didemnid ascidian Lissoclinum patella. ISME J 6:1222-1237. https://doi.org/10.1038/ismej.2011.181

6. Birrer SC, Dafforn KA, Sun MY, Williams RBH, Potts J, Scanes P, Kelaher BP, Simpson SL, Kjelleberg S, Swarup S, Steinberg P, Johnston EL (2019) Using meta-omics of contaminated sediments to monitor changes in pathways relevant to climate regulation. Environ Microbiol 21:389-401. https://doi.org/10.1111/1462-2920.14470

7. Caporaso JG, Kuczynski J, Stombaugh J, Bittinger K, Bushman FD, Costello EK, Fierer N, Peña AG, Goodrich JK, Gordon JI, Huttley GA, Kelley ST, Knights D, Koenig JE, Ley RE, Lozupone CA, McDonald D, Muegge BD, Pirrung M, Reeder J, Sevinsky JR, Turnbaugh PJ, Walters WA, Widmann J, Yatsunenko T, Zaneveld J, Knight R (2010) QIIME allows analysis of high-throughput community sequencing data. Nat Methods 7:335-336. https://doi.org/10.1038/nmeth.f.303

8. Carey CJ, Michael Beman J, Eviner VT, Malmstrom CM, Hart SC (2015) Soil microbial community structure is unaltered by plant invasion, vegetation clipping, and nitrogen fertilization in experimental semi-arid grasslands. Front Microbiol 6:466. https://doi.org/10.3389/fmicb.2015.00466

9. Casanoves F, Pla L, Di Rienzo JA, Díaz S (2011) FDiversity: A software package for the integrated analysis of functional diversity. Methods Ecol Evol 2:233-237. https://doi.org/10.1111/j.2041-210X.2010.00082.x

10. Chen QL, Ding J, Li CY, Yan ZZ, He JZ, Hu HW (2020) Microbial functional attributes, rather than taxonomic attributes, drive top soil respiration, nitrification and denitrification processes. Sci Total Environ 734:139479. https://doi.org/10.1016/j.scitotenv.2020.139479 
11. Chen W, Ren K, Isabwe A, Chen H, Liu M, Yang J (2019) Correction to: Stochastic processes shape microeukaryotic community assembly in a subtropical river across wet and dry seasons (Microbiome (2019) 7:1 (138) D0I: 10.1186/s40168-019-0749-8). Microbiome 7:138. https://doi.org/10.1186/s40168-019-0763-x

12. Chevallereau A, Pons BJ, van Houte S, Westra ER (2021) Interactions between bacterial and phage communities in natural environments. Nat Rev Microbiol. https://doi.org/10.1038/s41579-021-00602-y

13. Craig H, Antwis RE, Cordero I, Ashworth D, Robinson CH, Osborne TZ, Bardgett RD, Rowntree JK, Simpson LT (2021) Nitrogen addition alters composition, diversity, and functioning of microbial communities in mangrove soils: An incubation experiment. Soil Biol Biochem 153:108076. https://doi.org/10.1016/j.soilbio.2020.108076

14. Cui J, Yuan X, Zhang Q, Zhou J, Lin K, Xu J, Zeng Y, Wu Y, Cheng L, Zeng Q, Mei K, Chen Y (2021) Nutrient availability is a dominant predictor of soil bacterial and fungal community composition after nitrogen addition in subtropical acidic forests. PLoS One 16:e0246263. https://doi.org/10.1371/journal.pone.0246263

15. Cui Y, Zhang Y, Duan C, Wang X, Zhang X, Ju W, Chen H, Yue S, Wang Y, Li S, Fang L (2020) Ecoenzymatic stoichiometry reveals microbial phosphorus limitation decreases the nitrogen cycling potential of soils in semi-arid agricultural ecosystems. Soil Tillage Res 197:104463. https://doi.org/10.1016/j.still.2019.104463

16. Dai W, Zhang J, Tu Q, Deng Y, Qiu Q, Xiong J (2017) Bacterioplankton assembly and interspecies interaction indicating increasing coastal eutrophication. Chemosphere 177:317-325. https://doi.org/10.1016/j.chemosphere.2017.03.034

17. Dai Z, Su W, Chen H, Barberán A, Zhao H, Yu M, Yu L, Brookes PC, Schadt CW, Chang SX, Xu J (2018) Long-term nitrogen fertilization decreases bacterial diversity and favors the growth of Actinobacteria and Proteobacteria in agro-ecosystems across the globe. Glob Chang Biol 24:3452-3461. https://doi.org/10.1111/gcb.14163

18. Dini-Andreote F, Stegen JC, Van Elsas JD, Salles JF (2015) Disentangling mechanisms that mediate the balance between stochastic and deterministic processes in microbial succession. Proc Natl Acad Sci U S A 112:E1326-E1332. https://doi.org/10.1073/pnas.1414261112

19. Fierer N, Lauber CL, Ramirez KS, Zaneveld J, Bradford MA, Knight R (2012) Comparative metagenomic, phylogenetic and physiological analyses of soil microbial communities across nitrogen gradients. ISME J 6:1007-1017. https://doi.org/10.1038/ismej.2011.159

20. Freedman ZB, Romanowicz KJ, Upchurch RA, Zak DR (2015) Differential responses of total and active soil microbial communities to long-term experimental N deposition. Soil Biol Biochem 90:275-282. https://doi.org/10.1016/j.soilbio.2015.08.014

21. Friedman J, Alm EJ (2012) Inferring Correlation Networks from Genomic Survey Data. PLoS Comput Biol 8:e1002687. https://doi.org/10.1371/journal.pcbi.1002687

22. Guo Q, Wen Z, Zheng C, Li W, Fan Y, Zhu D (2021) Effects of Robinia pseudoacacia on the undergrowth of herbaceous plants and soil properties in the Loess Plateau of China. J Plant Ecol 14:896-910. https://doi.org/10.1093/jpe/rtab041

23. Huang J, Xu Y, Yu H, Zhu W, Wang P, Wang B, Na X (2021) Soil prokaryotic community shows no response to 2 years of simulated nitrogen deposition in an arid ecosystem in northwestern China. Environ Microbiol 23:1222-1237. https://doi.org/10.1111/14622920.15364

24. Jones L, Provins A, Holland M, Mills G, Hayes F, Emmett B, Hall J, Sheppard L, Smith R, Sutton M, Hicks K, Ashmore M, Haines-Young R, Harper-Simmonds $L$ (2014) A review and application of the evidence for nitrogen impacts on ecosystem services. Ecosyst Serv 7:76-88. https://doi.org/10.1016/j.ecoser.2013.09.001

25. Lefcheck JS (2016) piecewiseSEM: Piecewise structural equation modelling in $r$ for ecology, evolution, and systematics. Methods Ecol Evol 7:573-579. https://doi.org/10.1111/2041-210X.12512

26. Leff JW, Jones SE, Prober SM, Barberán A, Borer ET, Firn JL, Harpole WS, Hobbie SE, Hofmockel KS, Knops JMH, McCulley RL, La Pierre K, Risch AC, Seabloom EW, Schütz M, Steenbock C, Stevens CJ, Fierer N (2015) Consistent responses of soil microbial communities to elevated nutrient inputs in grasslands across the globe. Proc Natl Acad Sci U S A 112:10967-10972. https://doi.org/10.1073/pnas.1508382112

27. Li H, Xu Z, Yang S, Li X, Top EM, Wang R, Zhang Y, Cai J, Yao F, Han X, Jiang Y (2016) Responses of Soil Bacterial Communities to Nitrogen Deposition and Precipitation Increment Are Closely Linked with Aboveground Community Variation. Microb Ecol 71:974989. https://doi.org/10.1007/s00248-016-0730-z

28. Li J, Li Z, Wang F, Zou B, Chen Y, Zhao J, Mo Q, Li Y, Li X, Xia H (2015) Effects of nitrogen and phosphorus addition on soil microbial community in a secondary tropical forest of China. Biol Fertil Soils 51:207-215. https://doi.org/10.1007/s00374-014-0964-1 
29. Li J, Sang C, Yang J, Qu L, Xia Z, Sun H, Jiang P, Wang X, He H, Wang C (2021) Stoichiometric imbalance and microbial community regulate microbial elements use efficiencies under nitrogen addition. Soil Biol Biochem 156:108207.

https://doi.org/10.1016/j.soilbio.2021.108207

30. Liang S, Wang J (2020) In Advanced Remote Sensing. Academic Press, London.

31. Liang Y, Xiao X, Nuccio EE, Yuan M, Zhang N, Xue K, Cohan FM, Zhou J, Sun B (2020) Differentiation strategies of soil rare and abundant microbial taxa in response to changing climatic regimes. Environ Microbiol 22:1327-1340. https://doi.org/10.1111/14622920.14945

32. Liu C, Yao M, Stegen JC, Rui J, Li J, Li X (2017) Long-term nitrogen addition affects the phylogenetic turnover of soil microbial community responding to moisture pulse. Sci Rep 7:17492. https://doi.org/10.1038/s41598-017-17736-w

33. Liu J, Meng Z, Liu X, Zhang XH (2019) Microbial assembly, interaction, functioning, activity and diversification: a review derived from community compositional data. Mar Life Sci Technol 1:112-128. https://doi.org/10.1007/s42995-019-00004-3

34. Liu W, Fu S, Wu S, Zhong Z, Xu Y, Deng J, Ren C, Han X, Zhang Q, Su Y (2020) Nutrient limitations for overstory and understory plants during Robinia pseudoacacia afforestation in the Loess Plateau, China. Soil Sci Soc Am J 84:888-900. https://doi.org/10.1002/saj2.20059

35. Liu X, Duan L, Mo J, Du E, Shen J, Lu X, Zhang Y, Zhou X, He C, Zhang F (2011) Nitrogen deposition and its ecological impact in China: An overview. Environ Pollut 159:2251-2264. https://doi.org/10.1016/j.envpol.2010.08.002

36. Liu X, Zhang Y, Han W, Tang A, Shen J, Cui Z, Vitousek P, Erisman JW, Goulding K, Christie P, Fangmeier A, Zhang F (2013) Enhanced nitrogen deposition over China. Nature 494:459-462. https://doi.org/10.1038/nature11917

37. Lu M, Yang Y, Luo Y, Fang C, Zhou X, Chen J, Yang X, Li B (2011) Responses of ecosystem nitrogen cycle to nitrogen addition: A meta-analysis. New Phytol 189:1040-1050. https://doi.org/10.1111/j.1469-8137.2010.03563.x

38. Lu X, Vitousek PM, Mao Q, Gilliam FS, Luo Y, Turner BL, Zhou G, Mo J (2021) Nitrogen deposition accelerates soil carbon sequestration in tropical forests. Proc Natl Acad Sci U S A 118:e2020790118. https://doi.org/10.1073/pnas.2020790118

39. Luan L, Liang C, Chen L, Wang H, Xu Q, Jiang Y, Sun B (2020) Coupling Bacterial Community Assembly to Microbial Metabolism across Soil Profiles. mSystems 5:e00298-20. https://doi.org/10.1128/msystems.00298-20

40. Lv F, Xue S, Wang G, Zhang C (2017) Nitrogen addition shifts the microbial community in the rhizosphere of Pinus tabuliformis in Northwestern China. PLoS One 12:e0172382. https://doi.org/10.1371/journal.pone.0172382

41. Magoč T, Salzberg SL (2011) FLASH: Fast length adjustment of short reads to improve genome assemblies. Bioinformatics 27:2957-2963. https://doi.org/10.1093/bioinformatics/btr507

42. Markovskaja S, Kačergius A (2014) Morphological and molecular characterisation of Periconia pseudobyssoides sp. nov. and closely related P. byssoides. Mycol Prog 13:291-302. https://doi.org/10.1007/s11557-013-0914-6

43. McHugh TA, Morrissey EM, Mueller RC, Gallegos-Graves LV, Kuske CR, Reed SC (2017) Bacterial, fungal, and plant communities exhibit no biomass or compositional response to two years of simulated nitrogen deposition in a semiarid grassland. Environ Microbiol 19:1600-1611. https://doi.org/10.1111/1462-2920.13678

44. Mo Y, Peng F, Gao X, Xiao P, Logares R, Jeppesen E, Ren K, Xue Y, Yang J (2021) Low shifts in salinity determined assembly processes and network stability of microeukaryotic plankton communities in a subtropical urban reservoir. Microbiome 9:128. https://doi.org/10.1186/s40168-021-01079-w

45. Nelson MB, Martiny AC, Martiny JBH (2016) Global biogeography of microbial nitrogen-cycling traits in soil. Proc Natl Acad Sci U S A 113:8033-8040. https://doi.org/10.1073/pnas.1601070113

46. Neuhauser S, Huber L, Kirchmair M (2011) Is Roesleria subterranea a primary pathogen or a minor parasite of grapevines? Risk assessment and a diagnostic decision scheme. Eur J Plant Pathol 130:503-510. https://doi.org/10.1007/s10658-011-9769-3

47. Osburn ED, Aylward FO, Barrett JE (2021) Historical land use has long-term effects on microbial community assembly processes in forest soils. ISME Commun 1:48. https://doi.org/10.1038/s43705-021-00051-x

48. Perronne R, Munoz F, Borgy B, Reboud X, Gaba S (2017) How to design trait-based analyses of community assembly mechanisms: Insights and guidelines from a literature review. Perspect Plant Ecol Evol Syst 25:29-44.

https://doi.org/10.1016/j.ppees.2017.01.004

49. Qin C, Zhu K, Chiariello NR, Field CB, Peay KG (2020) Fire history and plant community composition outweigh decadal multi-factor global change as drivers of microbial composition in an annual grassland. J Ecol 108:611-625. https://doi.org/10.1111/1365-

2745.13284

Page 12/17 
50. Quast C, Pruesse E, Yilmaz P, Gerken J, Schweer T, Yarza P, Peplies J, Glöckner FO (2013) The SILVA ribosomal RNA gene database project: Improved data processing and web-based tools. Nucleic Acids Res 41:590-596. https://doi.org/10.1093/nar/gks1219

51. Ramirez KS, Lauber CL, Knight R, Bradford MA, Fierer N (2010) Consistent effects of nitrogen fertilization on soil bacterial communities in contrasting systems. Ecology 91:3463-3470. https://doi.org/10.1890/10-0426.1

52. Robe P, Nalin R, Capellano C, Vogel TM, Simonet P (2003) Extraction of DNA from soil. Eur J Soil Biol 39:183-190. https://doi.org/10.1016/S1164-5563(03)00033-5

53. Roberts TL, Ross WJ, Norman RJ, Slaton NA, Wilson CE (2011) Predicting Nitrogen Fertilizer Needs for Rice in Arkansas Using Alkaline Hydrolyzable-Nitrogen. Soil Sci Soc Am J 75:1161-1171. https://doi.org/10.2136/sssaj2010.0145

54. Romdhane S, Spor A, Aubert J, Bru D, Breuil M-C, Hallin S, Mounier A, Ouadah S, Tsiknia M, Philippot L (2021) Unraveling negative biotic interactions determining soil microbial community assembly and functioning. ISME J. https://doi.org/10.1038/s41396-02101076-9

55. Sagova-Mareckova M, Omelka M, Cermak L, Kamenik Z, Olsovska J, Hackl E, Kopecky J, Hadacek F (2011) Microbial communities show parallels at sites with distinct litter and soil characteristics. Appl Environ Microbiol 77:7560-7567. https://doi.org/10.1128/AEM.00527-11

56. Sardans J, Alonso R, Janssens IA, Carnicer J, Vereseglou S, Rillig MC, Fernández-Martínez M, Sanders TGM, Peñuelas J (2016) Foliar and soil concentrations and stoichiometry of nitrogen and phosphorous across European Pinus sylvestris forests: Relationships with climate, N deposition and tree growth. Funct Ecol 30:676-689. https://doi.org/10.1111/1365-2435.12541

57. Segata N, Izard J, Waldron L, Gevers D, Miropolsky L, Garrett WS, Huttenhower C (2011) Metagenomic biomarker discovery and explanation. Genome Biol 12:R60. https://doi.org/10.1186/gb-2011-12-6-r60

58. She W, Bai Y, Zhang Y, Qin S, Feng W, Sun Y, Zheng J, Wu B (2018) Resource availability drives responses of soil microbial communities to short-term precipitation and nitrogen addition in a desert shrubland. Front Microbiol 9:186. https://doi.org/10.3389/fmicb.2018.00186

59. Sun R, Chen Y, Han W, Dong W, Zhang Y, Hu C, Liu B, Wang F (2020) Different contribution of species sorting and exogenous species immigration from manure to soil fungal diversity and community assemblage under long-term fertilization. Soil Biol Biochem 151:108049. https://doi.org/10.1016/j.soilbio.2020.108049

60. Tatarko AR, Knops JMH (2018) Nitrogen addition and ecosystem functioning: Both species abundances and traits alter community structure and function. Ecosphere 9:e02087. https://doi.org/10.1002/ecs2.2087

61. Toju H, Peay KG, Yamamichi M, Narisawa K, Hiruma K, Naito K, Fukuda S, Ushio M, Nakaoka S, Onoda Y, Yoshida K, Schlaeppi K, Bai Y, Sugiura R, Ichihashi Y, Minamisawa K, Kiers ET (2018) Core microbiomes for sustainable agroecosystems. Nat Plants 4:247-257. https://doi.org/10.1038/s41477-018-0139-4

62. Trivedi P, Delgado-Baquerizo M, Trivedi C, Hu H, Anderson IC, Jeffries TC, Zhou J, Singh BK (2016) Microbial regulation of the soil carbon cycle: Evidence from gene-enzyme relationships. ISME J 10:2593-2604. https://doi.org/10.1038/ismej.2016.65

63. Vitousek PM, Porder S, Houlton BZ, Chadwick OA (2010) Terrestrial phosphorus limitation: Mechanisms, implications, and nitrogenphosphorus interactions. Ecol Appl 20:5-15. https://doi.org/10.1890/08-0127.1

64. Wang C, Liu D, Bai E (2018a) Decreasing soil microbial diversity is associated with decreasing microbial biomass under nitrogen addition. Soil Biol Biochem 120:126-133. https://doi.org/10.1016/j.soilbio.2018.02.003

65. Wang C, Lu X, Mori T, Mao Q, Zhou K, Zhou G, Nie Y, Mo J (2018b) Responses of soil microbial community to continuous experimental nitrogen additions for 13 years in a nitrogen-rich tropical forest. Soil Biol Biochem 121:103-112. https://doi.org/10.1016/j.soilbio.2018.03.009

66. Wang H, Liu S, Zhang X, Mao Q, Li X, You Y, Wang J, Zheng M, Zhang W, Lu X, Mo J (2018c) Nitrogen addition reduces soil bacterial richness, while phosphorus addition alters community composition in an old-growth N-rich tropical forest in southern China. Soil Biol Biochem 127:22-30. https://doi.org/10.1016/j.soilbio.2018.08.022

67. Wen Z, Xu W, Li Q, Han M, Tang A, Zhang Y, Luo X, Shen J, Wang W, Li K, Pan Y, Zhang L, Li W, Collett JL, Zhong B, Wang X, Goulding K, Zhang F, Liu X (2020) Changes of nitrogen deposition in China from 1980 to 2018. Environ Int 144:106022. https://doi.org/10.1016/j.envint.2020.106022

68. Widdig M, Heintz-Buschart A, Schleuss PM, Guhr A, Borer ET, Seabloom EW, Spohn M (2020) Effects of nitrogen and phosphorus addition on microbial community composition and element cycling in a grassland soil. Soil Biol Biochem 151:108041. https://doi.org/10.1016/j.soilbio.2020.108041 
69. Wippel K, Tao K, Niu Y, Zgadzaj R, Kiel N, Guan R, Dahms E, Zhang P, Jensen DB, Logemann E, Radutoiu S, Schulze-Lefert P, GarridoOter R (2021) Host preference and invasiveness of commensal bacteria in the Lotus and Arabidopsis root microbiota. Nat Microbiol 6:1150-1162. https://doi.org/10.1038/s41564-021-00941-9

70. Wu J, Liu W, Zhang W, Shao Y, Duan H, Chen B, Wei X, Fan H (2019) Long-term nitrogen addition changes soil microbial community and litter decomposition rate in a subtropical forest. Appl Soil Ecol 142:43-51. https://doi.org/10.1016/j.apsoil.2019.05.014

71. Xiao Y, Li C, Yang Y, Peng Y, Yang Y, Zhou G (2020) Soil Fungal Community Composition, Not Assembly Process, Was Altered by Nitrogen Addition and Precipitation Changes at an Alpine Steppe. Front Microbiol 11:579072. https://doi.org/10.3389/fmicb.2020.579072

72. Xu L, Xing A, Du E, Shen H, Yan Z, Jiang L, Tian D, Hu H, Fang J (2021) Effects of nitrogen addition on leaf nutrient stoichiometry in an old-growth boreal forest. Ecosphere 12:e03335. https://doi.org/10.1002/ecs2.3335

73. Xu W, Luo XS, Pan YP, Zhang L, Tang AH, Shen JL, Zhang Y, Li KH, Wu QH, Yang DW, Zhang YY, Xue J, Li WQ, Li QQ, Tang L, Lu SH, Liang T, Tong YA, Liu P, Zhang Q, Xiong ZQ, Shi XJ, Wu LH, Shi WQ, Tian K, Zhong XH, Shi K, Tang QY, Zhang LJ, Huang JL, He CE, Kuang FH, Zhu B, Liu H, Jin X, Xin YJ, Shi XK, Du EZ, Dore AJ, Tang S, Collett JL, Goulding K, Zhang FS, Liu XJ (2015) Quantifying atmospheric nitrogen deposition through a nationwide monitoring network across China. Atmos Chem Phys Discuss 15:1836518405. https://doi.org/10.5194/acpd-15-18365-2015

74. Yang H, Li Y, Wu M, Zhang Z, Li L, Wan S (2011) Plant community responses to nitrogen addition and increased precipitation: The importance of water availability and species traits. Glob Chang Biol 17:2936-2944. https://doi.org/10.1111/j.13652486.2011.02423.x

75. Yang Y, Cheng H, Gao H, An S (2020) Response and driving factors of soil microbial diversity related to global nitrogen addition. $\mathrm{L}$ Degrad Dev 31:190-204. https://doi.org/10.1002/ldr.3439

76. Yevdokimov I, Larionova A, Blagodatskaya E (2016) Microbial immobilisation of phosphorus in soils exposed to drying-rewetting and freeze-thawing cycles. Biol Fertil Soils 52:685-696. https://doi.org/10.1007/s00374-016-1112-x

77. Yin Y, Wang Y, Li S, Liu Y, Zhao W, Ma Y, Bao G (2019) Soil microbial character response to plant community variation after grazing prohibition for 10 years in a Qinghai-Tibetan alpine meadow. Plant Soil 458:175-189. https://doi.org/10.1007/s11104-019-04044-7

78. You C, Wu F, Yang W, Xu Z, Tan B, Yue K, Ni X (2018) Nutrient-limited conditions determine the responses of foliar nitrogen and phosphorus stoichiometry to nitrogen addition: A global meta-analysis. Environ Pollut 241:740-749. https://doi.org/10.1016/j.envpol.2018.06.018

79. Zeng J, Liu X, Song L, Lin X, Zhang H, Shen C, Chu H (2016) Nitrogen fertilization directly affects soil bacterial diversity and indirectly affects bacterial community composition. Soil Biol Biochem 92:41-49. https://doi.org/10.1016/j.soilbio.2015.09.018

80. Zhang C, Liu G, Xue S, Wang G (2016) Soil bacterial community dynamics reflect changes in plant community and soil properties during the secondary succession of abandoned farmland in the Loess Plateau. Soil Biol Biochem 97:40-49. https://doi.org/10.1016/j.soilbio.2016.02.013

81. Zhang H, Li W, Adams HD, Wang A, Wu J, Jin C, Guan D, Yuan F (2018a) Responses of woody plant functional traits to nitrogen addition: A meta-analysis of leaf economics, gas exchange, and hydraulic traits. Front Plant Sci 9:683. https://doi.org/10.3389/fpls.2018.00683

82. Zhang T, Chen HYH, Ruan H (2018b) Global negative effects of nitrogen deposition on soil microbes. ISME J 12:1817-1825. https://doi.org/10.1038/s41396-018-0096-y

83. Zheng LL, Zhao Q, Yu ZY, Zhao SY, Zeng DH (2017) Altered leaf functional traits by nitrogen addition in a nutrient-poor pine plantation: A consequence of decreased phosphorus availability. Sci Rep 7:7415. https://doi.org/10.1038/s41598-017-07170-3

84. Zhou Z, Wang C, Luo Y (2020) Meta-analysis of the impacts of global change factors on soil microbial diversity and functionality. Nat Commun 11:3072. https://doi.org/10.1038/s41467-020-16881-7

85. Zhu J, Chen Z, Wang Q, Xu L, He N, Jia Y, Zhang Q, Yu G (2020) Potential transition in the effects of atmospheric nitrogen deposition in China. Environ Pollut 258:113739. https://doi.org/10.1016/j.envpol.2019.113739

\section{Figures}



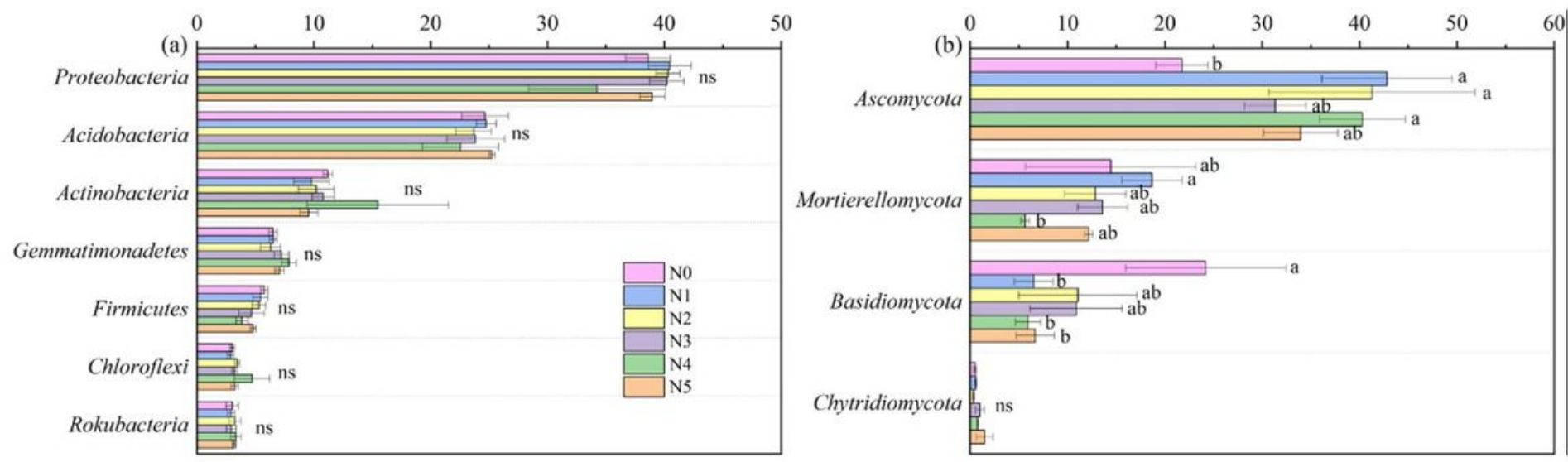

\section{Figure 1}

Changes in the relative abundances of bacteria (a) and fungi (b) across the $\mathrm{N}$ addition treatments (at the phylum level). The average relative abundance was estimated as a ratio between the abundance of the sequence type and the total number of sequences $(n=3)$ using normalized data. Different letters above bars within each taxon indicate significant differences $(P<0.05)$. The ns indicates no significant difference $(P>0.05)$.
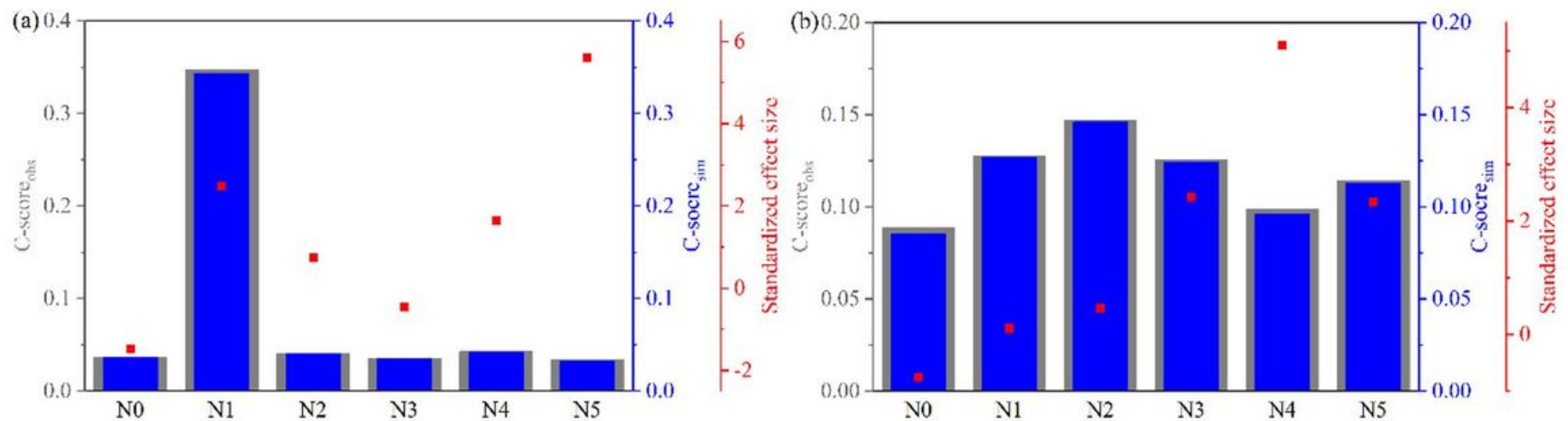

\section{Figure 2}

Ecological processes shaping the bacterial (a) and fungal (b) community assembly. The checkerboard score (C-score) was used to test the null hypothesis of the assembly process No significant differences between the values of observed C-scores (C-scoreobs) and simulated C-scores (C-scoresim) indicate a random co-occurrence pattern. The significant difference between the values of C-scoreobs and $\mathrm{C}$-scoresim indicates a non-random co-occurrence pattern. A standardized effect size (SES) of $<-2$ and $>2$ represents aggregation and segregation, respectively. For more details on the analysis of C-score in these communities, see Supplementary Table S2. 

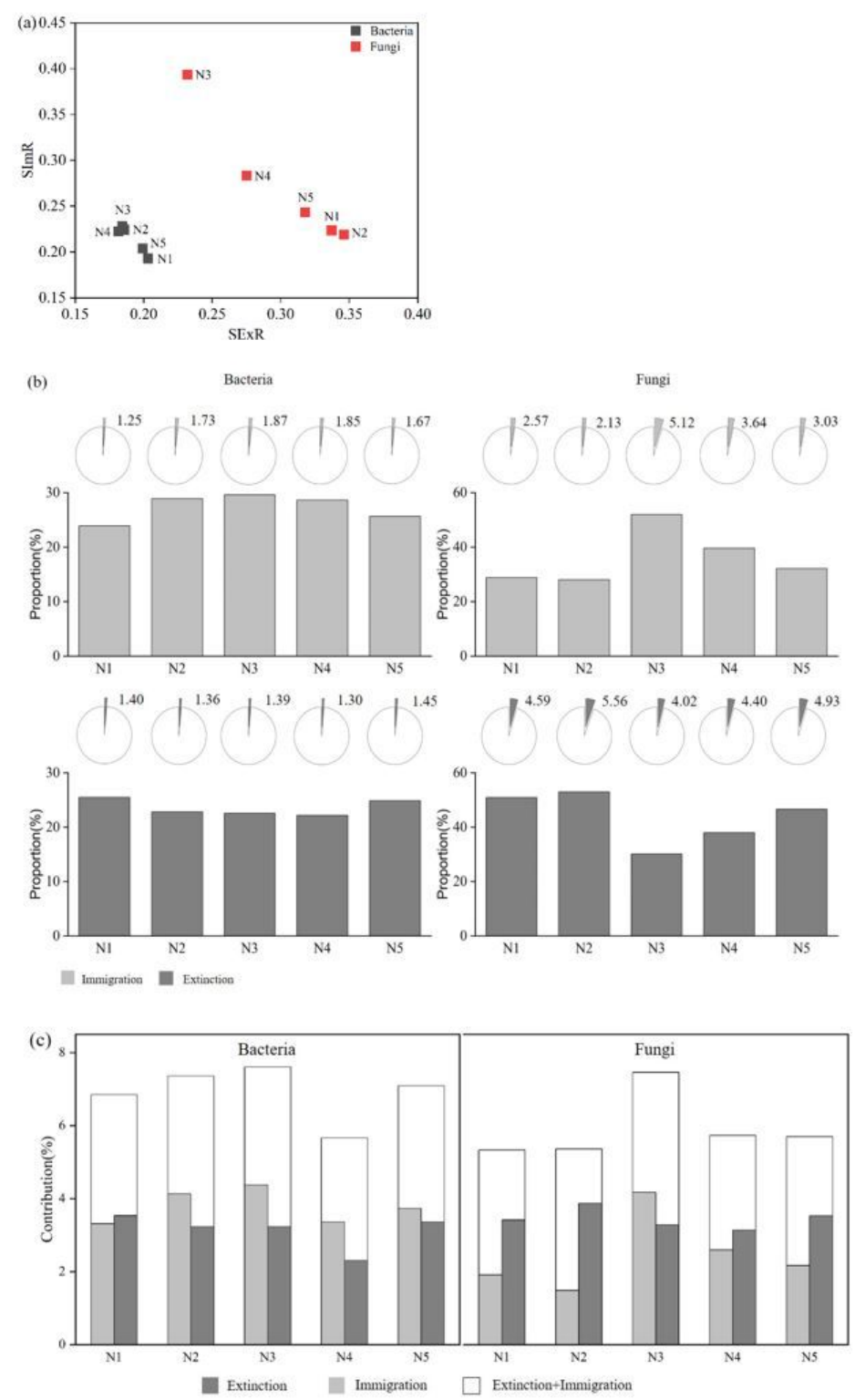

\section{Figure 3}

Effects of $\mathrm{N}$ addition on microbial community extinction and immigration. (a) Bivariate plot between SExR (species-extinct ratio) and SImR (species-immigration ratio). (b) The contribution of extinct and immigrated OTUs to bacterial and fungal OTU abundance and community compositions under different $\mathrm{N}$ addition treatments. The bar charts show the percentage of extinct and immigrated OTUs in total OTU numbers, and the pie charts illustrates the relative abundance of extinct and immigrated OTUs in the soil bacterial and fungal communities. (c) The contribution of extinct and immigrated OTUs to the dissimilarity of the bacterial and fungal communities between $\mathrm{N}$ addition treatments and control. 

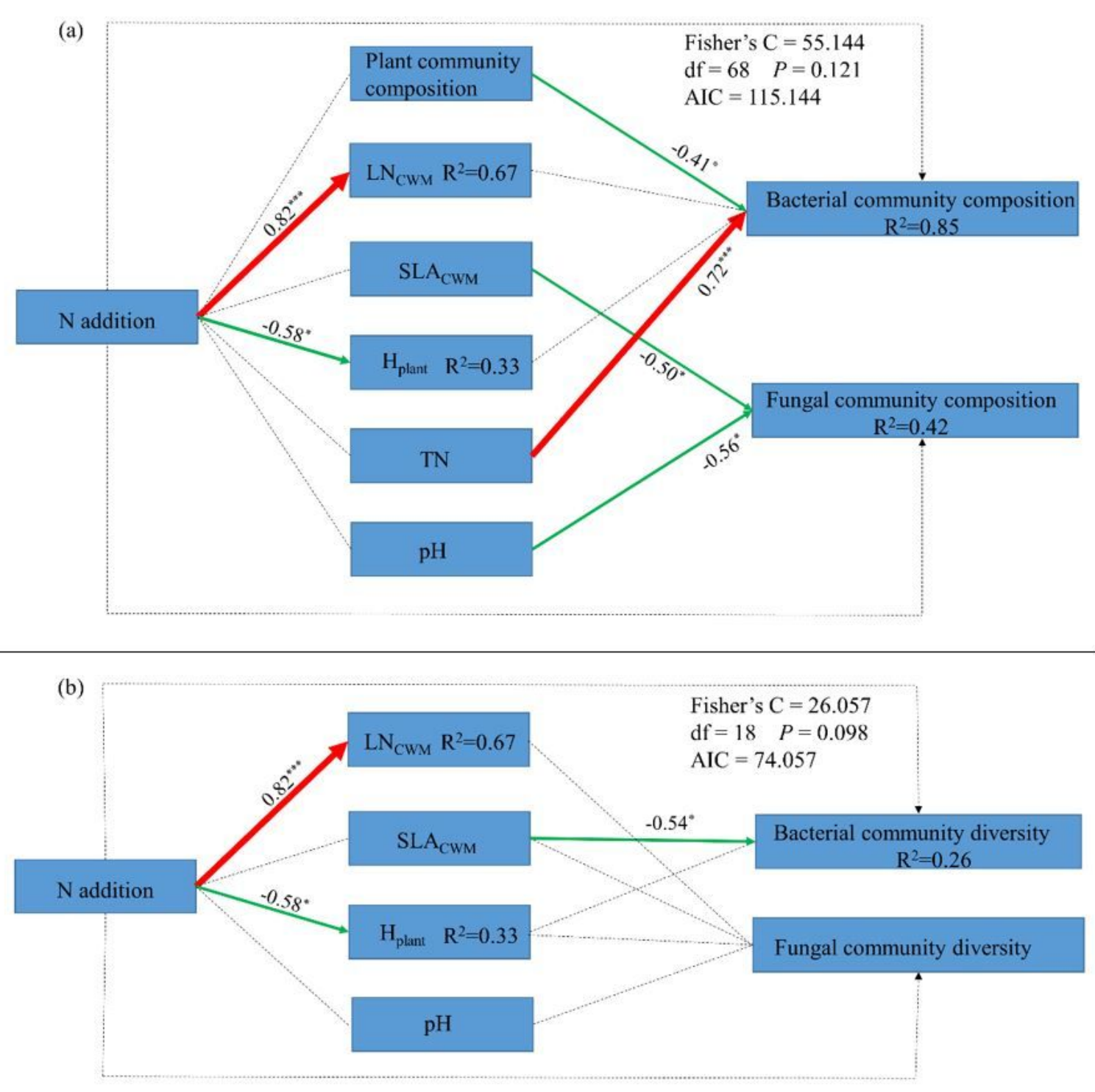

\section{Figure 4}

The structural equation model showing the effects of vegetation characteristics and soil properties on soil microbial compositions (a) and diversity (b). Numbers adjacent to arrows are standardized path coefficients, and the width of the arrow is proportional to the strength of the path coefficient. The red line indicates significant positive correlation, the green line indicates significant negative correlation, and the dotted line indicates insignificant correlation. Significance levels: * indicates $P<0.05$ and *** indicates $P<0.001$. R2 is the proportion of variance explained.

\section{Supplementary Files}

This is a list of supplementary files associated with this preprint. Click to download.

- Guoetalsuppermentary.docx 